\title{
CONVERSION AS THE PATH TO THE RECOVERY OF HUMANITY IN THE CONTEXT OF ST JOHN PAUL II'S THEOLOGY OF HOLINESS
}

\author{
M A G D A B UŠK OVÁ
}

\begin{abstract}
The study focuses on Pope John Paul II's view of conversion as an essential aspect of holiness. It explores why he emphasises the personal conversion of a Christian to God, and in a broader context, how conversion relates to the recovery of humanity and human dignity. The reflection is based on the teaching of the Second Vatican Council, especially as presented in the documents Gaudium et Spes and Lumen Gentium. Conversion is viewed from the perspective of spiritual theology and the union between God and the human person and focuses on some related features from John Paul II's 'Trinitarian' group of encyclicals. The reflection also examines the importance of Christian conversion to God as an internal process of transformation in the human person in the context of both internal ruptures and external existential threats.
\end{abstract}

Keywords

John Paul II; Conversion; Holiness; Union with Christ; Mercy; Human Dignity

DOI: $10.14712 / 23363398.2021 .6$

$I_{1}$

has been in the habit of recent popes, especially John Paul II and Francis, to draw attention to contemporary trends in society, where the pressure to perform is becoming ever greater, societal and cultural processes are constantly accelerating, and material matters are holding centre stage. Today, for Christians and non-Christians alike, and on both individual and societal levels, what is external and visible is generally preferred over the internal and the invisible. This preference often leads to a rupture within human beings as individuals and in society as a whole, a rupture which threatens humanity itself. 
On top of all this come external threats such as the global health crisis. However, one of the principal tasks of Christianity is to remind human beings of their inner essence - that the problems faced by individuals, society, and the Church are not rooted in external structures. It is vital to remember the inner life, the heart, where human beings receive the love of God. The Church should address itself to structural problems but must focus on what is in the heart and search for solutions to protect and develop the humanity of human beings and in so doing protect and develop their relationship with God.

The popes respond to these trends by exhorting Christians to focus on the inner life and to seek a change in the heart. In this context, there is an emphasis on Christian conversion, which is an integral part of St John Paul II's theology of holiness. ${ }^{1}$ Although there is a timeless element of conversion, John Paul II reflects on the current situation of the individual and of the ecclesial environment:

Conversion is the most concrete expression of the working of love and of the presence of mercy in the human world. The true and proper meaning of mercy does not consist only in looking, however penetratingly and compassionately, at moral, physical or material evil: mercy is manifested in its true and proper aspect when it restores to value, promotes and draws good from all the forms of evil existing in the world and in man (DM 6). ${ }^{2}$

Why does John Paul II emphasise the personal conversion of a Christian to God? In a broader context, how does conversion relate to the recovery of humanity and human dignity?

As the beginning of the Christian journey, baptism is the believer's response to the appeal of Jesus: "The right time has come", [Jesus] said, "and the Kingdom of God is near! Turn away from your sins and believe the Good News!''(Mark 1:15). The primary conversion is necessary as 'in the baptism of faith [believers] truly become sons of God and sharers in the divine nature. In this way they are really made holy ...

\footnotetext{
1 This reflection on conversion is closely linked to my previous research on John Paul II's theology of holiness presented in the defended licentiate work, 'The Theology of Holiness According to St John Paul II in the Encyclicals of His Pontificate' (Prague: Charles University, 2021, unpublished).

2 John Paul II, Dives in Misericordia, 30 November 1980, accessed 10 January 2021, https://bit.ly/2UHeF9h.
} 
for through baptism as through a door men enter the Church' (Lumen Gentium 14, 40).

This study will explore three aspects of conversion: (a) the significant role conversion plays in St John Paul II's theology of holiness; (b) the concept of a 'second conversion'3 or 'permanent conversion', ${ }^{4}$ and the commitment of a Christian to continue on the path of holiness in the Church; (c) conversion as viewed particularly through the perspective of the encyclical Dives in Misericordia (DM).

Regarding methodology, the study takes the approach of spiritual theology with a focus on 'the union of man with God in Christ'. ${ }^{5}$ This focus on conversion as an aspect of holiness, which in turn is interpreted as 'union with Christ' (LG 50), is the golden thread of the study.

John Paul II reflects on conversion and the context of conversion in his encyclical Dives in Misericordia but also offers significant reflections in the encyclicals Redemptor Hominis $(\mathrm{RH})^{6}$ and Dominum et Vivificantem (DV). ${ }^{7}$ The three encyclicals complete the Pope's Trinitarian group of encyclicals. ${ }^{8}$ The Italian theologian Luciano Meddi considers it essential to reflect on the subject of conversion in the documents of the Magisterium. He takes the view that 'a global reading of the most important conciliar and post-conciliar documents helps us to understand that the theme of conversion shares a Trinitarian nature'. ${ }^{9}$

3 The Catechism reminds us that 'Christ's call to conversion continues to resound in the lives of Christians. This second conversion is an uninterrupted task for the whole Church who, "clasping sinners to her bosom, (is) at once holy and always in need of purification, (and) follows constantly the path of penance and renewal" (LG 8)' 'Catechism of the Catholic Church,' n.d., para. 1428, accessed 10 January 2021, https:// www.vatican.va/archive/ENG0015/_P49.HTM.

4 The term 'permanent conversion' can be found, for example, in the work of Luciano Meddi, 'The Spirituality of Conversion,' The Person and the Challenges 6, no. 2 (2016): 227, doi: http://dx.doi.org/10.15633/pch.1904, and Roland Lacroix, 'Conversion - The Act, the Process and Accompaniment,' The Person and the Challenges 6, no. 2 (2016): 262, doi: http://dx.doi.org/10.15633/pch.1905.

5 Pavel Kohut, Co je spirituální teologie? (Kostelní Vydří: Karmelitánské nakladatelství, 2007), 34, (my translation).

6 John Paul II, Redemptor Hominis, 4 March 1979, accessed 10 January 2021, https://bit $.1 y / 3 \mathrm{drWvz} 5$.

7 John Paul II, Dominum et Vivificantem, 18 May 1986, accessed 10 January 2021, https://bit.ly/3x8wIDR.

8 See Nigel Zimmermann, 'John Paul II and the Significance of the Trinity for Human Dignity: "Ipsa autem iam hic in terris adest", Australian eJournal of Theology 20, no. 2 (August 2013), 108-121, here 114, accessed 10 March 2021, https://bit.ly/3w5V3sG.

9 Meddi, 'The Spirituality of Conversion,' 230-231. Meddi also comments: 'Magisterial reflections often refer to the subject of spirituality as a way of conversion, as 
Although the encyclicals represent the collective work of the Magisterium, it is the Pope's personal view that we read in the encyclicals: it is his signature at the bottom.

\section{Conversion and its Perspectives}

An emphasis on inner personal conversion is a traditional perspective of the Church's teaching, both among the Church Fathers and in medieval theology. It is a classic motif and one that is sometimes forgotten today. This chapter will approach conversion from the perspective of biblical theology, in the teaching of the Second Vatican Council, and in a number of selected authors showing facets of conversion.

A biblical perspective on the word 'conversion' covers various stances and understandings. It proposes 'conversion' (Greek $\mu \varepsilon \tau \alpha v o l \alpha$; Latin conversiō) as representing an internal change: 'the biblical metanoia; primarily any sort of religious or moral transformation, especially the radical venture of entrusting oneself to God and his gracious guidance by a radical and fundamental religious act'.$^{10}$ For the entry 'conversion' the Lexham Bible Dictionary uses the expression 'غ̇ $\pi 1 \sigma \tau \rho \varepsilon ́ \varphi \omega$, epistrephō, change of mind', which 'in Judaism, refers to initiation into adherence to the Torah, especially by circumcision. In Christianity, [it] refers to initiation into the Church of Christ, especially by baptism. In both, conversion refers to a turning from old ways to the practices of a new faith. ${ }^{11}$ The Anchor Bible Dictionary notes some inconsistency in the use of the English word 'conversion' in translations and proposes using

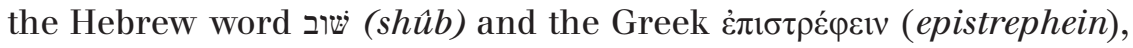
both of which translate as 'to turn'. ${ }^{12}$ It refers to the need to consider not only 'particular words but an examination of the varying imagery for conversion', ${ }^{13}$ which leads to consideration of various examples of conversion. In Mark 1:15 and Acts 20:21, conversion 'consists of an exercise of repentance and faith, which Christ and Paul link together

a Trinitarian reference and as a development of different dimensions inside the person.' Meddi, 'The Spirituality of Conversion,' 238.

10 Karl Rahner, Dictionary of Theology (New York: Crossroad, 1981), 97.

11 John D. Barry (Editor) The Lexham Bible Dictionary, (Bellingham: Lexham Press, 2016), accessed 10 March 2021, https://www.logos.com/product/36564 /lexham-bible-dictionary.

12 David Noel Freedman (Editor-in-Chief), The Anchor Bible Dictionary, Volume I A-C (New York: Doubleday, 1992), 1131.

13 Ibid., 1131. 
as summing up between them the moral demand of the gospel'. ${ }^{14}$ Such an understanding can serve as a unifying starting point for our topic and provide a summary of the biblical view of conversion: 'repentance means a change of mind and heart towards God: faith means belief of His word and trust in His Christ; conversion covers both'. ${ }^{15}$ Limbeck adds a comment regarding Jesus' words in the Gospel of Mark, 'Repent and believe the gospel' (Mark 1:15 NJB), ${ }^{16}$ after which Jesus changes his appeal from repentance to following Him. ${ }^{17}$ This shift towards an understanding of conversion not only as repentance but as following Jesus offers a key contribution to this study and its perspective on the continual character of conversion.

The Second Vatican Council brought refreshment to the Church and offered new approaches, such as the significant involvement of the laity in the life and mission of the Church and an emphasis on the call to holiness for all Christians. In the context of primary conversion, baptism is the gateway to the path of holiness and the prospect of eternal life. The call to be a holy people begins with baptism (LG 40); it is 'the baptismal call to holiness'. ${ }^{18}$ The concept of a second conversion concerns the need to live an authentic life according to the Gospel and to answer the call of the Second Vatican Council to continue living a life of holiness (LG 39-42). Before this Council, the Church largely associated holiness with the religious and the clergy, although not to the exclusion of the laity. However, the Council shifted the context of holiness to include the laity to a more elevated degree: holiness can be attained in all vocations; the vocations may differ, but 'holiness is one' (LG 41). Direct references to conversion can be found in several places, such as the constitutions Lumen Gentium (LG 11, 35, 46) and Sacrosanctum Concilium (SC 9), and, in the context of the mission of the Church, in the decree Ad Gentes (AD 13, 40). It is necessary to determine the character of conversion, however. Rush, who reflects on the conciliar and post-conciliar ecclesial dimension of conversion, states that the Second Vatican Council 'called for conversion on all levels of ecclesial

\footnotetext{
Douglas, The New Bible Dictionary, (Grand Rapids, Mich.: Eerdmans, 1962), 251.

Douglas, The New Bible Dictionary, 251.

New Jerusalem Bible, n.d., accessed 1 June 2021, https://bit.ly/3qyP3Hu.

17 Meinard Limbeck, Stuttgarter Kleiner Kommentar, Neues Testament, 21 Bde. in 22 Tl. -Bdn., Bd.2, Markus-Evangelium, (Stuttgart: Verlag Katholisches Bibelwerk, 1984), 29.

18 Brian P. Flanagan, 'The Universal Call to Holiness and Laity in the Church,' Toronto Journal of Theology 32, no. 2 (2016): 219-232, 219.
} 
life: personal, collective, institutional, and structural'. ${ }^{19}$ Here, Rush confirms the Council's high call for the conversion of individuals although he believes that 'setting up any sharp dichotomy between any of these levels-for example, between the spiritual renewal of individuals in the Church, and organizational, structural reform of the institutional Church - is a false dichotomy.' ${ }^{\text {'20 }}$

The interpretation of what conversion means also depends on the approach taken by a particular theological view and research context. As Lacroix emphasises, "work on conversion calls not only to specify the vocabulary, but also to clarify the concept of conversion in its various facets'. ${ }^{21}$ The past decade has seen a number of articles published on the theme of conversion as reflected in this study. ${ }^{22}$ The valuable contributions, such as that from Ormond Rush, reflect on the ecclesial and personal character of conversion as presented by the Second Vatican Council. ${ }^{23}$ Frývaldský describes the progression from the personal to the ecclesial, exploring the 'issue of Christian identification with the Church' in the context of J. Ratzinger's description of moving 'from the private "self" to the ecclesial "self". The emphasis here is on a detachment from oneself in favour of an inner attachment to Christ, which is realised in the identification with the Church. ${ }^{24}$

From the point of view of spiritual theology, although Meddi focuses more on the catechetical approach, he deals with 'the spiritual dimension of conversion'.$^{25}$ Grygiel suggests that 'every human being requires a change of life, that is, a conversion to the truth that begins to unveil itself in the gift'. ${ }^{26}$ Meddi also highlights this unmerited character of

19 Ormond Rush, 'Ecclesial Conversion After Vatican II: Renewing "The Face of the Church" to reflect "the Genuine Face of God", Theological Studies 74, no. 4 (2014): 788, doi: 10.1177/004056391307400401.

20 Rush, 'Ecclesial Conversion After Vatican II,' 788.

21 Lacroix, 'Conversion,' 262.

22 For example, Rush, 'Ecclesial Conversion After Vatican II,' 785-803; Meddi, 'The Spirituality of Conversion,' 227-259; Lacroix, 'Conversion,' 261-265.

23 Rush, 'Ecclesial Conversion After Vatican II,' 785-803.

24 Pavel Frývaldský, “Bez církve mizí Kristus v minulosti, bez Krista se stává církev pouhou organizací." Vztah Krista a církve v díle Josepha Ratzingera - Benedikta XVI.,' AUC Theologica 2, no. 1 (2012), 87-111, here 99-101, doi: https://doi.org/10 $.14712 / 23363398.2015 .49$, (my translation).

25 Meddi, 'The Spirituality of Conversion,' 227-259, 228.

26 Stanisław Grygiel, Discovering the Human Person. In Conversation with John Paul II (Michigan: Eerdmans, 2014), 109. 
conversion, drawing on John Paul II's Redemptoris Missio, ${ }^{27}$ which states that conversion is 'a gift of God, a work of the Blessed Trinity' (RM 46). ${ }^{28}$

Lacroix, who deals with the theme of conversion from the perspective of catechesis, emphasises its ecclesial character and suggests that 'permanent conversion' is 'the preferred method of "remaining in faith"', ${ }^{29}$ In this respect, Lacroix reminds us that the essence of conversion concerns the internal, the invisible, just as the writer to the Hebrews insists that, "to have faith is to be sure of the things we hope for, to be certain of the things we cannot see' (Heb 11:1). ${ }^{30}$

Regarding conversion as a method, spiritual theology views it as providing a clearer understanding of what is primarily invisible but nonetheless desirable for union with God. Conversion is essentially a way for a Christian to approach life and tackle spiritual obstacles; ${ }^{31}$ it refers to "the struggle of Christian life. This is the struggle of conversion directed toward holiness and eternal life to which the Lord never ceases to call us' ${ }^{32}$ The emphasis on the call of Jesus leads to another dimension or expression of conversion highlighted by Lacroix, namely, 'a conversion that lasts, that unfolds in Christian life itself seen as a vocation'. ${ }^{33}$

It appears, however, that personal conversion as an aspect of holiness, as described by John Paul II, receives relatively less attention from many authors and that the topic is not fully covered. This study, therefore, aims to provide a contribution to the discussion and, in so doing, to redress the balance in some small way.

27 John Paul II, Redemptoris Missio, 7 December 1990, accessed 10 January 2021, https:// bit.ly/3w65P1S.

28 Meddi, 'The Spirituality of Conversion,' 232.

29 Lacroix, 'Conversion,' 263.

30 Unless stated otherwise, Bible quotations are from the Catholic Good News Bible: Catholic Good News Bible with Deuterocanonical Books/Apocrypha (London: The Bible Societies/Collins, 2005).

31 See also, 'Catechism of the Catholic Church,' n.d., para. 1426, accessed 10 January 2021, https://www.vatican.va/archive/ENG0015/_P48.HTM.

32 'Catechism of the Catholic Church,' n.d., para. 14 $\overline{26}$, accessed 10 January 2021, https:// www.vatican.va/archive/ENG0015/_P48.HTM.

33 Lacroix, 'Conversion,' 264. 


\section{Conversion as an Aspect of St John Paul II's Theology of Holiness}

In his theological writings, especially in the Trinitarian group of encyclicals, John Paul II views conversion ${ }^{34}$ as an essential aspect of holiness. He is clearly seeking to draw our attention to something extraordinary. At the beginning of his pontificate, the new Pope announced that his primary task was to 'complete the implementation of the Second Vatican Council'. ${ }^{35}$ Extracts from the pastoral constitution Gaudium et Spes and the dogmatic constitution Lumen Gentium are often quoted in the Trinitarian encyclicals. There are two strands to the Pope's interpretation of the Council teaching. The first is the idea of holiness, particularly 'the universal call to holiness' ${ }^{36}$ which was one of the key emphases of his pontificate. In his theology of holiness, he develops the theme of this universal call, highlighting the statement of the Council Fathers that, 'by His incarnation the Son of God has united Himself in some fashion with every man' (GS 22), and further developing the concept of holiness as union with Christ in the Church (cf. RH 13). A clear understanding of the call to holiness can be found in the Pope's post-synodal apostolic letter Christifideles Laici, especially in the paragraph 16, where he urges that 'all Christians take up again the way of gospel renewal, welcoming in a spirit of generosity the invitation expressed by the apostle Peter "to be holy in all conduct" (1 Pt 1:15)'. ${ }^{37}$ The second strand of his teaching on holiness, to which conversion is integral, can be identified as his focus on the fact that people know themselves fully only in 'the light of Christ' (GS 10, cf. GS 22).

34 Although this study focuses on personal conversion, it is worth noting that John Paul II also reflects on 'the need for interior conversion' in the context of ecumenical dialogue and of sins, where 'not only personal sins must be forgiven and left behind, but also social sins, which is to say the sinful "structures" themselves which have contributed and can still contribute to division and to the reinforcing of division' John Paul II, Ut Unum Sint, 25 May 1995, para. 34, accessed 1 June 2021, https://bit.ly/3h5QWbz.

35 George Weigel, Witness to Hope. The Biography of John Paul II (New York, NY: HarperCollins, 2001), 267-268.

36 See Vatican Council II, Lumen Gentium, paras. 39-42, 21 November 1964, https://bit .ly/3dt7ojQ.

37 John Paul II, Christifideles Laici, 30 December 1988, accessed 1 June 2021, https://bit $. l y / 362 X y 4 c$. The Pope also emphasises here the Trinitarian character of the call to holiness for the laity: "the prime and fundamental vocation that the Father assigns to each of them in Jesus Christ through the Holy Spirit: the vocation to holiness, that is, the perfection of charity,' para 16. 
In the Trinitarian encyclicals, the word 'conversion' is often found in the expressions such as 'true conversion' (RH 16, DM 4, DV 42), 'constant, ever more profound conversion' (RH 20), and 'authentic conversion' (DV 45). In various contexts, it can be further identified that John Paul II speaks of conversion as having both a permanent and a continual character.

The Pope introduces his initial encyclical Redemptor Hominis as follows: "the Redeemer of Man, Jesus Christ, is the centre of the universe and history' (RH 1). ${ }^{38}$ These words set the tone for the encyclical, determine its character, and penetrate the whole document. Spinello, who makes a detailed analysis of all 14 encyclicals, states that 'the Pope's principal purpose in this encyclical is to embrace and deepen the Christocentrism of the Second Vatican Council and to explore the truth about the human person revealed by the Son'. ${ }^{39}$ As an aspect of holiness interpreted as achieving union with Christ, the theme of conversion is situated into the mystery of Redemption. Conversion is viewed here both as an initial event expressed in baptism and as a permanent or continual process that affects the whole of life. ${ }^{40}$

The anthropological character of John Paul II's approach ${ }^{41}$ to holiness consists in his great love and care for human beings in the light of Christ's redemption. Several points in Redemptor Hominis relate to the focus of this study on the permanent or 'continual conversion' (LG 35)

38 From Nigel Zimmermann's well-structured and well-arranged study on human dignity as interpreted by John Paul II we see the connection between conversion and human dignity in that both have a 'continual' aspect: 'for John Paul II, human dignity is in need of a Christocentric guide because it is anything but a universally accepted concept. Rather, human dignity requires an ongoing attentiveness if it is to serve the good of the human person with any success.' Nigel Zimmermann, 'John Paul II and the Significance of the Trinity for Human Dignity,' 110. Spinello, The Encyclicals of John Paul II, 79.

40 The outward expression of initial and 'continual conversion' (LG 35) is an integral part of a life of holiness. Furthermore, 'the vocation to holiness is intimately connected to mission and to the responsibility entrusted to the lay faithful in the Church and in the world' John Paul II, Christifideles Laici, para. 17.

41 For the theology and anthropology of John Paul II see, for example, Ronald D. Lawler, The Christian Personalism of Pope John Paul II (Chicago, Ill.: Franciscan Herald Press, 1982); George H. Williams, The Mind of John Paul II: Origins of His Thought and Action (New York: Seabury Press, 1981); Deborah Savage, The Subjective Dimension of Human Work. The Conversion of the Acting Person According to Karol Wojtyla/ John Paul II and Bernard Lonergan (New York: Peter Lang Publishing, 2008); John J. Coughlin, 'Pope John Paul II and the Dignity of the Human Being,' Harv. J.L. \& Pub. Pol'y 27, no. 1 (2003-2004): 65-79, accessed 1 June 2021, https://scholarship.law. nd.edu/law_faculty_scholarship/494/. 
of the Christian. One of these is the Christocentric emphasis: 'Jesus Christ is the stable principle and fixed centre of the mission that God himself entrusted to man' (RH 11). This statement is followed by a reference to the mission of the Church, by which John Paul II develops the ecclesial character of the mission but insists that 'the conversion that is begun by the mission is a work of grace, in which man must fully find himself again' (RH 12). Although conversion is set in an ecclesial and baptismal context, personal conversion, especially permanent conversion, is described as being reliant on God's grace. In seeing conversion as an aspect of holiness consisting in the union of man with God, both the personal and the ecclesial are in view. There is an essential connection between conversion and fully finding oneself only in God, and here the Pope connects the teachings of Gaudium et Spes and Dignitatis Humanae $^{42}$ (RH 12): 'the Church therefore sees its fundamental task in enabling that union to be brought about and renewed continually' (RH 13). The words 'renewed continually' can be considered synonymous with conversion. In relation to conciliar teaching, Rush speaks of 'the spiritual renewal of individuals in the Church'. ${ }^{43}$

Another aspect of personal conversion that John Paul II discusses is the importance of the sacrament of the Eucharist and Penance: '[Jesus'] right to meet each one of us in that key moment in the soul's life constituted by the moment of conversion and forgiveness' (RH 20). The Eucharist is a traditional practice of the Church, so why is the Pope putting so much emphasis on permanent or continual personal conversion here? He believes that:

without this constant ever renewed endeavour for conversion, partaking of the Eucharist would lack its full redeeming effectiveness and there would be a loss or at least a weakening of the special readiness to offer God the spiritual sacrifice (cf. 1 Pet 2:5) in which our sharing in the priesthood of Christ is expressed in an essential and universal manner (RH 20).

42 Paul VI, Dignitatis Humanae, 7 December 1965, accessed 10 January 2021, https://bit $. l y / 3 y 9 b J R e$.

43 Rush, 'Ecclesial Conversion After Vatican II,' 788. Concerning ecclesial conversion, Rush mentions terms such as 'renewal, purification, reform, restoration, change, updating, adaption, and development' and he states that 'of these "renewal" and "renew" (renovatio and renovare) are the most often used'. Rush, 'Ecclesial Conversion After Vatican II,' 787. 
Conversion, therefore, enables Christians 'to be ready', day by day, to follow Christ, to give their lives to Christ and put him at the centre. This permanent readiness of the Christian is connected with the aspect of God's love that is called mercy: 'love is greater than sin, than weakness ... it is a love always ready to raise up and forgive... in man's history, this revelation of love and mercy has taken a form and a name: that of Jesus Christ' (RH 9). Christians are called to follow this loving dimension of the spiritual life and to do it consciously. If a person's faith in Christ is not lived out consciously, this may be a sign that the person lacks real faith, deep faith, and authentic faith, which John Paul II sees as the visible fruit of conversion.

This is why everyday inner spiritual conversion is so essential. It is about following Christ as a disciple through daily conversion, being ready and able to love and to forgive, and preserving and developing faith and holiness (LG 40). ${ }^{44}$ 'True conversion' (RH 16) has an inner and individual-personal character ( $\mathrm{RH} 20$ ), and the beginning and end is in Christ. Conversion as an unceasing, spiritual act is integral to holiness interpreted as union with Christ. Conversion could also be seen in words that Jesus might address to us: You follow me, imitate me, but do you really believe in me, in the depths of your heart?

\section{Can Conversion Serve as a Path to the Recovery of Humanity and Human Dignity through Mercy?}

In his encyclical Dives in Misericordia ${ }^{45}$ the Pope begins with an outline of the Old Testament view of conversion, where the context of conversion is the sins and infidelity of the people of God who repeatedly failed to keep the covenant (DM 4). There is an emphasis on the need for the relationship between God and human beings to be renewed: 'whenever it became aware of its infidelity ... it appealed to mercy'

44 On baptised followers of Christ, the constitution also states that, 'by God's gift, they must hold on to and complete in their lives this holiness they have received.' Lumen Gentium, para. 40.

45 This study does not aim to address the many rich and beautiful themes within the encyclical. Rather, the focus is on conversion, on which John Paul II places great emphasis, and on suggesting why he might have placed such an emphasis. The spiritual background of the encyclical was influenced by the spirituality of St Faustyna Kowalska (see Spinello, The Encyclicals of John Paul II, 80). It also integrates spiritual experience with Karol Wojtyla's own father, and his spiritual father Cardinal Sapieha. Weigel, Witness to Hope, 386-387. 
(DM 4). If God 'finds repentance and true conversion', divine grace comes to the people again: '[Mercy] signifies a special power of love, which prevails over the sin and infidelity of the chosen people' (DM 4). The Pope focuses on the particular situations of people in need of healing through divine mercy, which is inseparable from conversion. Mercy is available for 'individuals languishing in a state of guilt or enduring every kind of suffering and misfortune. Both physical evil and moral evil, namely sin, cause the sons and daughters of Israel to turn to the Lord and beseech His mercy' (DM 4).

Conversion is presented as an authentic change of mind directly related to a relationship with the Lord. Conversion is, therefore, the renewal of that relationship, where 'mercy is the content of intimacy with [the] Lord, the content of [a] dialogue with Him' (DM 4). It can be inferred that repentance and conversion are key to uniting with God. Here we see the Pope's strong anthropological interest in human beings, in their life situations, which he presents as an opportunity for finding a solution through conversion to God's mercy.

Alongside mercy, other concepts of interest that are related to conversion include humanity as a state and quality of human being with a Christocentric character ${ }^{46}$ and human dignity. John Paul II states that 'mercy is an indispensable dimension of love; it is as it were love's second name' (DM 7). In a similar line of thinking, Kasper provides a valuable analysis of the concept of mercy, including an update for the twenty-first century. ${ }^{47}$ One of his key reflections deals with the question, 'how can we speak of a sympathetic - that is, a compassionate - God?'48 He notes a kind of fatigue surrounding the word 'mercy', which is rarely used and understood in society. ${ }^{49}$ However, as Kasper convincingly shows, even with regard to the tragedies and violence of the twentieth and twenty-first centuries, the word 'mercy' still keeps 'the correspond-

46 In this study, humanity is considered an individual state and quality of human being with its centre and character in Christ. Spinello provides a valuable insight into 'the nature of the human person' according to the view of John Paul II. Richard Spinello, The Genius of John Paul II. The Great Pope's Moral Wisdom (Lanham: Rowman \& Littlefield, 2007), 57-88.

47 Walter Kasper, Mercy. The Essence of the Gospel and the Key to Christian Life (New York: Paulist Press, 2014), 16-19. For the terminology and the related development of thinking regarding mercy, see Kasper, Mercy, 1-40.

48 Ibid., 19.

49 Ibid., 15. 
ing views and attitudes' and is even more urgent. ${ }^{50}$ The author points to the modern trend towards the use of words such as 'empathy' and 'compassion' to express what might formerly have been expressed by the word mercy and highlights their current importance in terms of people's ability to help one another in daily matters or extraordinary emergencies. ${ }^{51}$ He considers that 'one must understand the word compassion not only as compassionate behaviour. Rather, we must also hear in "compassion" the word "passion". This means discerning the cry for justice as well as making a passionate response to the appalling unjust relationships existing in our world'. ${ }^{52}$ It can be inferred that the concreteness of human distress is one of the essential components of the theme of conversion. However, Kasper also stresses that the theme of mercy 'concerns the message of God and his mercy, and only secondarily does it deal with the commandment for human behaviour that derives from it ${ }^{5},{ }^{5}$ and here we find a connection with the approach taken by John Paul II.

The central theme of the encyclical, by which the Pope seeks to bring an understanding of conversion and mercy, is the well-known Parable of the Prodigal Son (Luke 15:11-32). The parable speaks to the reality of various life situations and 'indirectly touches upon every breach of the covenant of love, every loss of grace, every sin' (DM 5). At the same time, it is a reflection that deeply touches on humanity itself and on human dignity (DM 5,6). Human dignity is a vast topic which features strongly in theological discussions. ${ }^{54}$ Nevertheless, I will seek to point out in this context why John Paul II emphasises the theme of conversion.

Humanity and human dignity were dealt with in great detail by the Second Vatican Council, particularly in the constitution Gaudium et Spes, which devotes a special chapter to Human Dignity (GS 12-22). As already noted, John Paul II set out to implement the teachings of the Council during his pontificate, ${ }^{55}$ and humanity and human dignity

\footnotetext{
Ibid., 1-5, 16.

Ibid., 16-19.

Ibid., 17.

Ibid., 18-19.

54 See, for example, Zimmermann, 'John Paul II and the Significance of the Trinity for Human Dignity.'

55 As Karol Wojtyla he actively participated in the preparation of the pastoral constitution Gaudium et Spes. He was a member of the sub-commission 'which had the task of studying the questions of the signs of the time' and of sub-commission no. $\mathrm{V}$ 'On the
} 
are among his key topics. There is no direct quotation from Gaudium et Spes in the passage on the Parable of the Prodigal Son, but we do find the reference right at the beginning of the encyclical in connection with human dignity:

We read in the Constitution Gaudium et Spes: 'Christ the new Adam...fully reveals man to himself and brings to light his lofty calling,' and does it 'in the very revelation of the mystery of the Father and of his love' (GS 22). The words that I have quoted are clear testimony to the fact that man cannot be manifested in the full dignity of his nature without reference - not only on the level of concepts but also in an integrally existential way - to God. Man and man's lofty calling are revealed in Christ through the revelation of the mystery of the Father and His love (DM 1).

If humanism considers human dignity to be of the highest value, then John Paul II can be said to propound a Christian humanism in which humanity and human dignity can be fully found only in God, in Christ (RH 11, RH 13, DM 1, and elsewhere). ${ }^{56}$ We find his understanding of humanity in, for example, his Letter to Families, which states that "the new [human] being is meant to express fully his humanity, to "find himself" as a person. ${ }^{57}$ The human being is, as we also read in the teaching of the Council, 'the only creature on earth whom God willed for its own sake'. ${ }^{8}$ The Pope closely associates genuine humanism with Christ (RH 10). Zimmermann observes that 'the centrality of the Second Person of the Trinity [Jesus] is crucial to his project, and serves the articulation of a human dignity informed by the witness of Christ, who illustrates the height of human dignity in his teaching and his work. ${ }^{59}$

role of the Church'. Skalický, Radost a naděje. Církev v dnešním světě (Kostelní Vydří: Karmelitánské nakladatelství, 2000), 90, 205.

56 In Christifideles Laici, the Pope reflects on the relationship between the call to holiness and dignity and stresses that 'holiness is the greatest testimony of the dignity conferred on a disciple of Christ.' John Paul II, Christifideles Laici, para 16. For more on the roots of John Paul II's personalism and his concept of the human person, see the comprehensive contribution (analytical in terms of both methodology and content) by František Burda, Obraz človéka ve filosofickém svétě Karola Wojtyly. The Czech book, with the translated title The image of a man in the philosophical world of Karol Wojtyla, contains a constructive summary in English. František Burda, Obraz človéka ve filosofickém svétě Karola Wojtyly (Ústí nad Orlicí: Oftis, 2011), 305-317.

${ }_{57}$ John Paul II, Letter to Families. Gratissimam Sane (1994), para. 9, accessed 10 March 2021, https://bit.ly/3js4QGB.

58 Ibid. See also Gaudium et Spes, para. 24.

59 Zimmermann, 'John Paul II and the Significance of the Trinity,' 110. 
True humanism, through Revelation, ascribes to the human person the dignity inherent to its nature and its eschatological hope: 'that dignity that springs from the relationship of the son with the father' (DM 5). We realise the true nature of human beings by following Jesus and thereby finding fullness and dignity. Nietzsche, by contrast, insists that people become entirely human only when they reject God, who resists the full realisation of humanity. ${ }^{60}$ He denies the fulness of man in faith and believes that 'the Christian faith, from the beginning, is sacrifice: the sacrifice of all freedom, all pride, all self-confidence of spirit; it is at the same time subjection, self-derision, and self-mutilation. ${ }^{61}$ It is in the context of the critique of the Christian faith, the designation of suffering as a sign of this faith and of the conversion of Christians to the cross, in which Nietzsche finds no love, only sacrifice, and this is unacceptable for him.

John Paul II clearly situates conversion in the context of mercy: 'conversion to God always consists in discovering His mercy' (DM 13). ${ }^{62}$ This statement does not exclude the possibility of conversion having a passive spiritual character, in the sense of listening, like Mary (Luke 10:39), but clearly indicates its dynamic character, seen in active ${ }^{63}$ meditation, discovering God in real-life situations, in prayer, or in following the example of the prodigal son. It may include making a firm decision to go to God the Father, admit to mistakes (DM 5), and receive the sacraments of the Eucharist and Penance (RH 7, RH 20, DM 13, DV 62).

Conversion brings an essential change. The 'awareness of squandered sonship' (DM 5) that we see in the prodigal son is recovered in Christ into full renewed dignity and the quality of life of the children of God: 'I will be your father, and you shall be my sons and daughters, says the Lord Almighty' (2 Cor 6:18). Such a promise can heal any kind of miserable situation, 'whenever tragedy strikes' (DM 4). Here we see how human suffering finds refuge and meaning in God's love and mercy. A person's suffering is not 'denied', as Nietzsche believes, ${ }^{64}$

60 Friedrich Nietzsche, Beyond Good and Evil, trans. L. A. Magnus (New York: Carlton House, 1930), para. 46, Friedrich Nietzsche, The Will to Power, ed. Walter Kaufmann (New York: Randome House, 1968), 506-507.

61 Ibid., para 46.

${ }_{62}$ The Latin version uses the verb retegere ('discover').

63 Zimmermann, 'John Paul II and the Significance of the Trinity,' 118. The author observers the active character of human being emphasised by John Paul II.

${ }_{64}$ Nietzsche, Beyond Good and Evil, para 46. 
but treated. The key truth of the parable and of the mercy shown by the father to his son(s) is that 'a fundamental good has been saved: the good of his son's humanity' (DM 6). This truth applies to other human situations and to any Christian. Mercy, then, renews and deepens union with Christ. Genuine conversion is not a one-off act, but 'all the beatitudes of the Sermon on the Mount indicate the way of conversion and of reform of life' (DM 14). Understood in this way, conversion leads through mercy to the recovery of the person's dignity, and this recovery consists of 'humanity... saved' (DM 6) and 'restored to value' (DM 6). Such inner recovery enables the Christian to cooperate in mercy, the practice of which is a 'gift' and 'task' for every Christian and for the Church (DM 14).

\section{Conversion as an Answer to 'Existential Fear' and Bad Times}

Recent Popes have drawn our attention to the threats that arise from the accelerated development of society, especially in the spheres of technology, the economy, and the environment. John Paul II speaks of 'sources of uneasiness': despite significant technical and other progress, 'in our world the feeling of being under threat is increasing. There is an increase of that existential fear' (DM 11).$^{65}$ In Dominum et Vivificantem the Pope analyses the nature of the threats arising from human nature (DV 36), from evil (DV 37, 38), and from the world. ${ }^{66}$ These threats are both external and internal. In the face of these threats, conversion becomes a way of constantly internalising one's life in Christ and of seeking and finding in his countenance the loving "countenance of the "Father of mercies and God of all comfort" (2 Cor 1:3)’ (DM 1).

Conversion is necessarily associated with the conscience and with the various roles of the Holy Spirit. Drawing on the Gospel of John, the Pope presents the Holy Spirit as the 'Spirit of truth' (Spiritus veritatis) (DV 3, 5ff), the Spirit 'Counselor' (Spiritus-Consolator) (DV 3, 4, 5ff), and the Spirit 'Paraclete' (Spiritus-Paraclitus) (DV 3, 7ff).

\footnotetext{
${ }_{65}$ For example, Kasper also reflects on the threats of the 20th and 21st centuries and associates with them the challenge of reflecting on God's mercy. Kasper, Mercy, 1-19.

${ }_{66}$ Zimmermann notes the Pope's warning concerning threats and fears in the context of his encyclicals Dives in Misericordia and Dominum et Vivificantem. Zimmermann, 'John Paul II and the Significance of the Trinity for Human Dignity', 115-116.
} 
To face these threats, to continue to mature in holiness, and come to a deeper unity with Christ, Christians must become adhered to Christ and his love and work with their conscience. Here, the Holy Spirit acts as a guide (DV 6, 27), helping to form Christians spiritually, primarily through the conscience, reminding them of Christ's words and teachings, and assuring them of love and the hope of 'eternal life' (DV 41). John Paul II is seeking to show that conversion is essential if a Christian is to live existentially in fullness and truth, as the conversion of the human heart, which is an indispensable condition for the forgiveness of sins, is brought about by the influence of the Counselor' (DV 42). Considering these approaches of John Paul II to conversion, it can be inferred that living a life of continual conversion under the guidance of the Holy Spirit brings an essential value: the ability to distinguish between converting first to God and then to the world, and therefore to be able rightly to prioritise the internal over the external and material.

Through a continual process of conversion, the Christian can be able to face fear and internal and external threats through being supported by the love of God through the Holy Spirit, who provides the strength needed to struggle against ${ }^{67}$ and face these threats (DV 58).

All of this is also expressed in the Pope's well-known motto: 'Do not be afraid. Open wide the doors to Christ.' ${ }^{68}$ In the Gospel, Jesus often strengthens and encourages his disciples: 'Peace is what I leave with you; it is my own peace that I give you. I do not give it as the world does. Do not be worried and upset; do not be afraid' (John 14:27). These existential fears and threats are still present and even accelerating and deepening under the current pressure of the coronavirus pandemic. ${ }^{6}$ Pope Francis also does not leave aside threats to the environment, the cause of which is mainly human consumption behaviour, and devel-

${ }^{67}$ A link between conversion and spiritual struggle can be found in the Council's appeal to laity to 'express [the hope in their hearts] by a continual conversion and by wrestling "against the world-rulers of this darkness, against the spiritual forces of wickedness" (Eph. 6:12)' (LG 35). The appeal applies to all Christians.

68 John Paul II, Homily of His Holiness John Paul II for the Inauguration of His Pontificate, 22 October 1978, para. 5, accessed 10 March 2021, https://bit.ly/3jyCL0B.

69 In the collection of his selected speeches, Pope Francis issues a call to conversion in order to face the current threats, especially the coronavirus pandemic. Pope Francis, Why Are You Afraid? Have You No Faith? The World Facing the Pandemic (Our Sunday Visitor Inc.U.S., 2021). 
ops the theme of conversion in his second encyclical Laudato $s i,{ }^{70}$ for example, John Paul II's strong appeal to 'ecological conversion' presented in his General Audience of 17 January 2001. ${ }^{71}$ John Paul II reflects this topic more in the context of the biblical perspective of human care of Earth, and Francis further shifts conversion onto a practical level, servicing each other while continuing the necessary internal transformation, thus placing a new emphasis on personal conversion. However, Francis also appeals that 'the ecological conversion needed to bring about lasting change is also a community conversion. ${ }^{72}$ In a later exhortation related to holiness, he adds: 'At times, life presents great challenges. Through them, the Lord calls us anew to a conversion that can make his grace more evident in our lives, 'in order that we may share his holiness' (Heb 12:10). At other times, we need only find a more perfect way of doing what we are already doing. ${ }^{73}$

\section{Conclusion}

One of the principal goals of Christianity, especially in times of accelerated internal and external pressures and threats, is to awaken human beings to their inner essence by appealing to them to seek a path primarily in the heart. The personal conversion of the Christian to God is an essential aspect of St John Paul II's theology of holiness; his encyclicals support the Trinitarian dimension of conversion. In the theological discourse, there is a significant understanding of conversion as the preservation and development of faith and as an internal spiritual process. Here, the approach applied has been that of spiritual theology with a focus on the union of God with the human person.

The significant role played by conversion in John Paul II's theology of holiness concerns its relation to integrity and the need for holiness. The anthropological and Christocentric characters of conversion are central to this theology, which the Pope develops from the teaching of

\footnotetext{
Francis, Laudato si', 24 May 2015, accessed 10 March 2021, https://bit.ly/3AdtGjy.

71 John Paul II, General Audience, 17 January 2001, para. 4, accessed 10 March 2021, https://bit.ly/2UJ64D2; Francis, Laudato si', 24 May 2015, para. 5, 216-221.

72 Francis, Laudato si', para. 219.

73 Francis, Gaudete et Exsultate, 19 March 2018, para. 17, accessed 10 March 2021, https://bit.ly/3qCNCI1.
} 
the Second Vatican Council, especially regarding the universal call to holiness and the full understanding of the human being in a Christological perspective.

John Paul II speaks of conversion as having both a permanent and a continual character, both of which are crucial to living a holy life and developing union with Christ. As such, the theme of conversion is situated into the mystery of Redemption. The personal and ecclesial characters of conversion are both reliant on God's grace.

A significant feature of conversion is a constant readiness to follow Christ, to love, to forgive, and in this respect, the sacraments of the Eucharist and of Penance are seen as essential to conversion and the conscious experiencing life with Christ. Conversion is not just a onetime affair but a lifelong process. Such conversion is often expressed as a true conversion.

John Paul II also discusses conversion through the perspective of mercy. Here the emphasis is on the need for renewal in the relationship between human beings and God: conversion is an authentic change of mind directly related to a relationship with the Lord. Mercy as the countenance of the Father renews and deepens union with Christ. Alongside mercy, other concepts of interest related to conversion include humanity, as a state and quality of human being with a Christocentric character, and human dignity. Conversion leads through mercy to the recovery of the person's dignity, and this recovery heals and renews humanity and human dignity.

In John Paul II's theology, conversion has a role to play in the daily spiritual struggle that takes place in the lives of those who follow Christ. Conversion is necessarily linked with the conscience and with the various roles of the Holy Spirit. John Paul II seeks to show that conversion is essential if a Christian is to live existentially in fullness and truth. Conversion brings an essential value: the ability to distinguish between converting first to God and then to the world and, therefore, the need to prioritise the internal over the external and material; it is the art of making the right decision guided by the Holy Spirit.

Ruptures and threats have their origin in human nature, in the world, and in evil. The continual process of conversion, being supported by God's love expressed as mercy through the Holy Spirit, helps a person face these fears and threats, both internal and external. Pope Francis offers a further challenge in calling Christians to concretise their conversion through service to others. 
The approach to personal conversion to God explored in this paper will benefit from further research, especially regarding the Church's appeal to Christians to follow the path of holiness in their personal lives, in the Church, and in society.

Catholic Theological Faculty, Charles University Thákurova 3 16000 Praha 6 Czech Republic

E-mail: magda.buskova@seznam.cz 